\title{
Profitability of Using Herbicide and Herbicide with Biostimulators in Potato Production
}

\author{
Iwona Mystkowska ${ }^{1 *}$, Krystyna Zarzecka², Marek Gugała ${ }^{2}$, Anna Sikorska ${ }^{3}$ \\ 1 Department of Dieteties, Pope John Paul II State School of Higher Education, Sidorska 95/97, 21-500 Biała \\ Podlaska, Poland \\ 2 Institute of Agriculture and Horticulture, University of Natural Sciences and Humanities in Siedlce, Prusa 14, \\ 08-110 Siedlce, Poland \\ 3 Department of Agriculture, Vocational State School of Ignacy Mościcki in Ciechanów, Narutowicza 9, 06-400 \\ Ciechanów, Poland \\ * Corresponding author's e-mail: imystkowska@op.pl
}

\begin{abstract}
The results of three years of research concerned the assessment of the profitability of table potato production depending on the control of weed infestation and the use of biostimulants: (1) control object, (2) Avatar 293ZC (clomazone + metribuzin), (3) Avatar 293ZC + biostimulator PlonoStart, (4) Avatar 293ZC + biostimulator Aminoplant, (5) Avatar 293ZC + biostimulator Agro-Sorb-Folium. The research material consisted of potato tubers of the Malaga variety coming from a field experiment carried out in 2018-2020 on medium soil, in a split-plot arrangement, as two-factorial in three replications. Mechanical and chemical treatments increased the marketable yield of tubers by an average of $37.4 \%$, and decreased the by-yield of tubers by an average of $23.9 \%$ compared to the control object. The direct surplus per 1 ha of cultivation ranged from PLN 3521.1 in the control object (1) to PLN 11277.9 in object (5) (herbicid + Agro-Sorb Folium).
\end{abstract}

Keywords: plant protectrion; costs; gross margin; potato.

\section{INTRODUCTION}

Potatoes are easily weeded plants due to: slow and long initial development of plants (4560 days) - from planting tubers to emergence, and then closing the rows, wide row spacing, fertilization with manure, which is a source of nutrients not only for the cultivated plant, but also for the segetal vegetation. In addition, cereals are the most common forecrop for potatoes, and their combine harvesting favours fruiting and shedding seeds of most species of weeds. Hence, good conditions are naturally created for their development, and the potato often loses to the weeds. Therefore, the potato requires many treatments carefully selected according to the condition and degree of weed infestation [Qasim et al. 2013; Urbanowicz, 2015], which at the same time guarantee profitability of production [Skarżyńska,
2008]. To protect the cultivated plant against weed infestation, mechanical and chemical treatments were used with the use of herbicide and herbicide with biostimulators. The action of biostimulators boils down to increasing the naturally occurring resistance or tolerance to a given stress factor in plants, increasing their vigour and vitality, making it easier for them to survive difficult conditions [Pavlista, 2011; Van Oosten et al. 2017, Bulgari et al. 2019, Drobek et al. 2019, Kahlel and Sultan 2019, Trawczyński 2021]. In agricultural production, not only the amount of the obtained crop is taken into account, but also the profitability of production, which is associated with the costs incurred for plant protection. Nowacki [2016] stated that the profitability of edible potato production varies in years, depending on the size of the national harvest, the place of sale of the commodity, as well as the import scale 
of early potatoes from other climatic zones. In the studies of Malyshev and Vinogradowa [2008] it was found that biostimulators, thanks to increasing the yield, increase the profitability of the production of a given plant. The aim of the research was to evaluate the profitability of the production of five methods of herbicide and herbicide application with biostimulators in the control of weed infestation in the potato Malaga cultivar.

\section{MATERIAL AND METHODS}

The research material was the yield of potato tubers (general, commercial and secondary) of the medium-early Malaga variety from a threeyear (2018-2020), a two-factor field experiment. The experiment was set up in triplicate with the split-plot method. Each year, before setting up the experiment, soil samples were taken for analysis. The soils in individual years differed in $\mathrm{pH} 5.25-5.42$ in $1 \mathrm{M} \mathrm{KCl}$, organic matter content 20.9-22.3 $\mathrm{g} \cdot \mathrm{kg}^{-1}$, and available macro-elements in $\mathrm{mg} \cdot \mathrm{kg}^{-1} \mathrm{P}-35.2-71.0, \mathrm{~K}-102.1-149.0, \mathrm{Mg}$ - 36.6-61.0. In the experiment, various variants of mechanical and chemical protection of potatoes against weeds were used and compared with purely mechanical treatments, which were the control object (1). Before emergence, the control object was dredged twice and dredged once, combined with harrowing, and after emergence, it was dredged twice, without herbicide and biostimulators. On objects mechanically and chemically weeded (2-5) before emergence, two dredging processes were applied, and immediately after the last dredging - about 7 days before the appearance of the first emergence of potato plants (BBCH $00-08$ ), chemical treatments with herbicide and herbicide with biostimulators, i.e.: (2) herbicide Avatar $293 \mathrm{ZC}-1.5 \mathrm{dm}^{3} \cdot \mathrm{ha}^{-1}$, (3) herbicide Avatar $293 \mathrm{ZC}-1.5 \mathrm{dm}^{3} \cdot \mathrm{ha}^{-1}+$ PlonoStart $2 \mathrm{dm}^{3} \cdot \mathrm{ha}^{-1}$ - use in two doses: a) 1.0 $\mathrm{dm}^{3} \cdot \mathrm{ha}^{-1}-$ full moon-end of emergence (BBCH phase 13-19) + b) $1.0 \mathrm{dm}^{3} \cdot \mathrm{ha}^{-1}$ - cover between rows $10-50 \%$ (BBCH phase 31-35), (4) herbicide Avatar $293 \mathrm{ZC}-1.5 \mathrm{dm}^{3} \cdot \mathrm{ha}^{-1}+$ Aminoplant $1.5 \mathrm{dm}^{3} \cdot \mathrm{ha}^{-1}$ - use in two doses: a) $1.0 \mathrm{dm}^{3} \cdot \mathrm{ha}^{-1}$ full moon-end of emergence $(\mathrm{BBCH}$ phase 13-19) + b) $0.5 \mathrm{dm}^{3} \cdot \mathrm{ha}^{-1}$ - cover between rows 10-50\% (BBCH phase 31-35), (5) herbicide Avatar $293 \mathrm{ZC}-1.5 \mathrm{dm}^{3} \cdot \mathrm{ha}^{-1}+$ Agro-Sorb Folium 4 $\mathrm{dm}^{3} \cdot \mathrm{ha}^{-1}$ - use in two doses: a) $2.0 \mathrm{dm}^{3} \cdot \mathrm{ha}^{-1}-$ full moon-end of emergence (BBCH phase 13-19) + b) $2.0 \mathrm{dm}^{3} \cdot \mathrm{ha}^{-1}$ - cover between rows $10-50 \%$ (before flowering) (BBCH phase 31-35). Herbicides and biostimulators were dissolved in 300 $\mathrm{dm}^{3}$ of water per 1 ha.

The selection of the herbicide Avatar 293 ZC was adjusted to the weed infestation, and the active substance of the preparation is clomazone $60 \mathrm{~g} \cdot \mathrm{dm}^{-3}(5.13 \%)$ and metribuzin $233 \mathrm{~g} \cdot \mathrm{dm}^{-3}$ (20.64\%). Biostimulators: Aminoplant $(9.48 \% \mathrm{~N}$, $9.2 \%$ amide nitrogen, free amino acids $-11.57 \%$, $87.7 \%$ organic substances), Agro-Sorb Folium ( $2.2 \%$ of nitrogen, $0.02 \%$ of manganese, $0.09 \%$ of zinc, total amino acid content $13.11 \%$ and free amino acid content $10.66 \%$ ), Plonostart (minerals with the addition of urea containing microorganisms: lactic acid bacteria and actinomycetes). The same fertilization was applies on all plots: manure at a dose of $25.0 \mathrm{t} / \mathrm{ha}$ in autumn and phosphorus-potassium mineral fertilization at the amount of $\mathrm{P}-44.0 \mathrm{~kg} \cdot \mathrm{ha}^{-1}$ and $\mathrm{K}-124.5 \mathrm{~kg} \cdot \mathrm{ha}^{-1}$. These fertilizers were ploughed in with pre-winter ploughing. Nitrogen fertilizers were sown in spring in the amount of $\mathrm{N} 100 \mathrm{~kg} \cdot \mathrm{ha}^{-1}$ and were mixed with the soil using a cultivator. The forecrop for potatoes in particular years of research was winter triticale. The potato plantation during the growing season was protected with insecticides: Actara $25 \mathrm{WG}$ (thiamethoxam) at a dose of $0.08 \mathrm{~kg} \cdot \mathrm{ha}^{-1}$, Decis Mega $50 \mathrm{EW}$ (deltamethrin) at a dose of $0.15 \mathrm{dm}^{3} \cdot \mathrm{ha}^{-1}$, Karate Zeon $050 \mathrm{CS}$ (lambdacyhalothrin) at a dose of $0.25 \mathrm{dm}^{3} \cdot \mathrm{ha}^{-1}$, Proteus $110 \mathrm{OD}$ at a dose of $0.4 \mathrm{dm}^{3} \cdot \mathrm{ha}^{-1}$ (thiacloprid, deltamethrin) and fungicides: Ridomil Gold MZ 68 WG (metalaxyl-M+mancozeb) at a dose of $2.0 \mathrm{~kg} \cdot \mathrm{ha}^{-1}$ and Dithane Neo Tec $75 \mathrm{WG}$ (mancozeb) at a dose of $2.5 \mathrm{~kg} \cdot \mathrm{ha}^{-1}$. The potato was planted by hand under the marker. At the time of harvest, the weight of tubers from each plot (with an area of $12.96 \mathrm{~m}^{2}$ ) was determined and converted into the yield per 1 ha. A $10 \mathrm{~kg}$ sample of tubers was also collected and the yield structure was analysed [Roztropowicz et al. 1999]. The marketable yield was potatoes with a diameter of more than $35 \mathrm{~mm}$, and tubers with internal and external defects, which constituted a secondary crop, were rejected. The values of yields and prices in individual years of research were adopted for the calculations [Dzwonkowski 2019, 2020]. For the calculations, the values of the trade and secondary yield as well as the purchase prices of materials and the sale of the yield were adopted as the average values from the three years of research. The direct costs 
include: seed potatoes, mineral and natural fertilizers (manure 50\%), plant protection chemicals, human work and operation of machines. Variable machine costs were calculated on the basis of the real parameters of the annual use of equipment and productivity on the farm as well as theoretical standards [Muzalewski 2015]. The measure of economic efficiency was the direct surplus, which is the difference between the value of the harvested crops and direct costs (without area payments) [Skarżyńska, 2008].

\section{RESULTS AND DISCUSSION}

The profitability of edible potato production depends on the size of the yield and the selling price. When analysing the edible potato of the Malaga cultivar yielding, it was found that it was differentiated depending on the herbicide and herbicide with a biostimulator used. The highest commercial yield was obtained after the application of the herbicide Avatar 293 ZC with the Agro-Sorb Folium biostimulator $-338.5 \mathrm{dt} \cdot \mathrm{ha}^{-1}$, while the lowest in the control object (without herbicide and biostimulator) $-220.5 \mathrm{dt} \cdot \mathrm{ha}^{-1}$. In the objects where mechanical and chemical tending with the use of herbicide and herbicide with a biostimulator (2.-5.) was applied, the commercial yield of tubers was on average $302.9 \mathrm{dt} \cdot \mathrm{ha}^{-1}$ and was higher than in the control object by 82.4 $\mathrm{dt} \cdot \mathrm{ha}^{-1}$. On the other hand, the secondary yield was on average $42.6 \mathrm{dt} \cdot \mathrm{ha}^{-1}$ (Table 1 ).

The value of the harvest is determined by the level of the total yield obtained by the producer, and in the case of edible potatoes, especially by the marketable yield, and the prices. Nowacki [2016] stated that an important element of the functioning of the potato market is the profitability of edible potato production resulting from the relations between the costs incurred by farmers and the obtained value of the harvests sold. When analysing the direct costs incurred for growing potatoes of the Malaga variety for research facilities, it can be concluded that they differed in terms of costs incurred for the purchase of plant protection products (herbicide with biostimulators), equipment operation and labour inputs. The costs of the herbicide and herbicide with biostimulators used in the research, compared to the total direct costs, ranged from 195.0 to $579.0 \mathrm{PLN} / \mathrm{ha}$ (Table 2), which accounted for $1.6-4.6 \%$ of the cost structure of potato cultivation, the most expensive was the use of the herbicide Avatar 293 ZC with the biostimulator Agro-Sorb Folium.

On the other hand, the costs of applied plant protection products (herbicides, insecticides, fungicides, biostimulators) accounted for from 5.1 to $9.6 \%$ of all costs. In the structure of potato cultivation costs, the costs of operating the equipment had the greatest share, from $29.5 \%$ on the object where the herbicide Avatar 293 ZC was applied to $32.7 \%$ on the control object (Fig. 1). According to Gołaś [2016], the cultivation of root crops depends on the technologies used related to the introduction of modern equipment, the use of which reduces the labour intensity of potato harvesting. The purchase costs of qualified seed potatoes had a significant share in the cost structure $-29.5-31.3 \%$ of all costs (Fig. 1). These results were confirmed in the studies by Skarżyńska [2010], Wereszczak and Marczakiewicz [2014], who stated that the purchase of certified seed potatoes is one of the most expensive expenses in potato cultivation. Fertilization

Table 1. Yielding of potatoes of variety Malaga (mean 2018-2020)

\begin{tabular}{|c|c|c|c|c|c|}
\hline \multirow{2}{*}{$\begin{array}{c}\text { Methods of application of herbicide and } \\
\text { biostimulants }\end{array}$} & \multicolumn{3}{|c|}{ Yield of potato [dt/ha] } & \multicolumn{2}{|c|}{$\begin{array}{c}\text { Increase of yield as compared to } \\
\text { that of object } 1 .\end{array}$} \\
\hline & total & market & side & market [\%] & side [\%] \\
\hline 1. Control object - mechanical weeding & 276.5 & 220.5 & 56.0 & $\begin{array}{c}--- \\
---\end{array}$ & $\begin{array}{c}---- \\
--\end{array}$ \\
\hline 2. Avatar $293 \mathrm{ZC} 1,5 \mathrm{dm}^{3} \cdot \mathrm{ha}^{-1}$ & 326.6 & 277.4 & 49.2 & 25.8 & -12.1 \\
\hline $\begin{array}{l}\text { 3. Avatar } 293 \mathrm{ZC} 1,5 \mathrm{dm}^{3} \cdot \mathrm{ha}^{-1}+ \\
\text { PlonoStart } 2,0 \mathrm{dm}^{3} \cdot \mathrm{ha}^{-1}\end{array}$ & 346.2 & 308.1 & 38.1 & 39.7 & -32.0 \\
\hline $\begin{array}{l}\text { 4. Avatar } 293 \mathrm{ZC} 1,5 \mathrm{dm}^{3} \cdot \mathrm{ha}^{-1}+ \\
\text { Aminoplant } 1,5 \mathrm{dm}^{3} \cdot \mathrm{ha}^{-1}\end{array}$ & 332.4 & 287.5 & 44.9 & 30.4 & -19.8 \\
\hline $\begin{array}{l}\text { 5. Avatar } 293 \text { ZC } 1,5 \mathrm{dm}^{3} \cdot \mathrm{ha}^{-1}+ \\
\text { Agro-Sorb Folium } 4 \mathrm{dm}^{3} \cdot \mathrm{ha}^{-1}\end{array}$ & 376.5 & 338.5 & 38.0 & 53.5 & -31.8 \\
\hline Średnio - Mean & 345.4 & 302.9 & 42.6 & 37.4 & 23.9 \\
\hline
\end{tabular}


Table 2. Direct costs and production value of ware potatoes of the Malaga variety (on average from years 20182020) in PLN/ha

\begin{tabular}{|l|c|c|c|c|c|}
\hline \multicolumn{1}{|c|}{ Specification } & Control object & Avatar 293 ZC & $\begin{array}{c}\text { Avatar 293 ZC }+ \\
\text { PlonoStart }\end{array}$ & $\begin{array}{c}\text { Avatar 293 ZC }+ \\
\text { Aminoplant }\end{array}$ & $\begin{array}{c}\text { Avatar 293 ZC }+ \\
\text { Agro-Sorb } \\
\text { Folium 4 }\end{array}$ \\
\hline Seed potato & 3725.0 & 3725.0 & 3725.0 & 3725.0 & 3725.0 \\
\hline Manure (50\%) & 1625.0 & 1625.0 & 1625.0 & 1625.0 & 1625.0 \\
\hline Mineral fertilizers: & 1148.3 & 1148.3 & 1148.3 & 1148.3 & 1148.3 \\
- nitrogen & 328.8 & 328.8 & 328.8 & 328.8 & 328.8 \\
- potassium & 450.0 & 450.0 & 450.0 & 450.0 & 450.0 \\
- phosphorus & 369.5 & 369.5 & 369.5 & 369.5 & 369.5 \\
\hline Plant protection agents: & 630.0 & 825.0 & 905.0 & 892.5 & 1209.0 \\
-herbicides & - & 195.0 & 195.0 & 195.0 & 195.0 \\
-insecticides & 297.0 & 297.0 & 297.0 & 297.0 & 337.0 \\
-fungicides & 333.0 & 333.0 & 333.0 & 333.0 & 38.0 \\
-biostimulatores & - & - & 80.0 & 1137.5 & 1137.5 \\
\hline Human work & 1192.3 & 1082.7 & 1137.5 & 3776.3 & 3776.3 \\
\hline Operation of the equipment & 4041.3 & 3511.3 & 3776.3 & 12304.6 & 12621.1 \\
\hline Direct costs per 1 ha & 12361.9 & 11917.3 & 12317.1 & 20125.0 & 23695.0 \\
\hline Value of market yield & 15435.0 & 19418.0 & 21567.0 & 359.2 & 304.0 \\
\hline Value of side yield & 448.0 & 393.6 & 304.8 & 20484.2 & 23999.0 \\
\hline Total production value & 15883.0 & 19811.6 & 21871.8 & 8179.6 & 11377.9 \\
\hline Gross margin for 1 ha of & 3521.1 & 7894.3 & 9554.7 & & \\
\hline cultivation & & & & & \\
\hline
\end{tabular}

in the form of manure constituted on average $13.2 \%$ of the cost structure, while mineral fertilization constituted on average $9.32 \%$ of the cost structure (Fig. 1). Direct costs per 1 ha of potato cultivation of the Malaga cultivar ranged from PLN 12361.9 on the control object to 12621.1 PLN/ha by applying of the herbicide clomazone + metribuzin with the biostimulator
Agro-Sorb-Folium (Table 2). The most expensive was the application of the herbicide clomazone + metribuzin with the biostimulator AgroSorb-Folium and the highest yield value was obtained from this object. The research shows that the production value of edible potato variety Malaga was diversified and ranged from 21871.8 PLN/ha to 23999.0 PLN/ha. The differences in

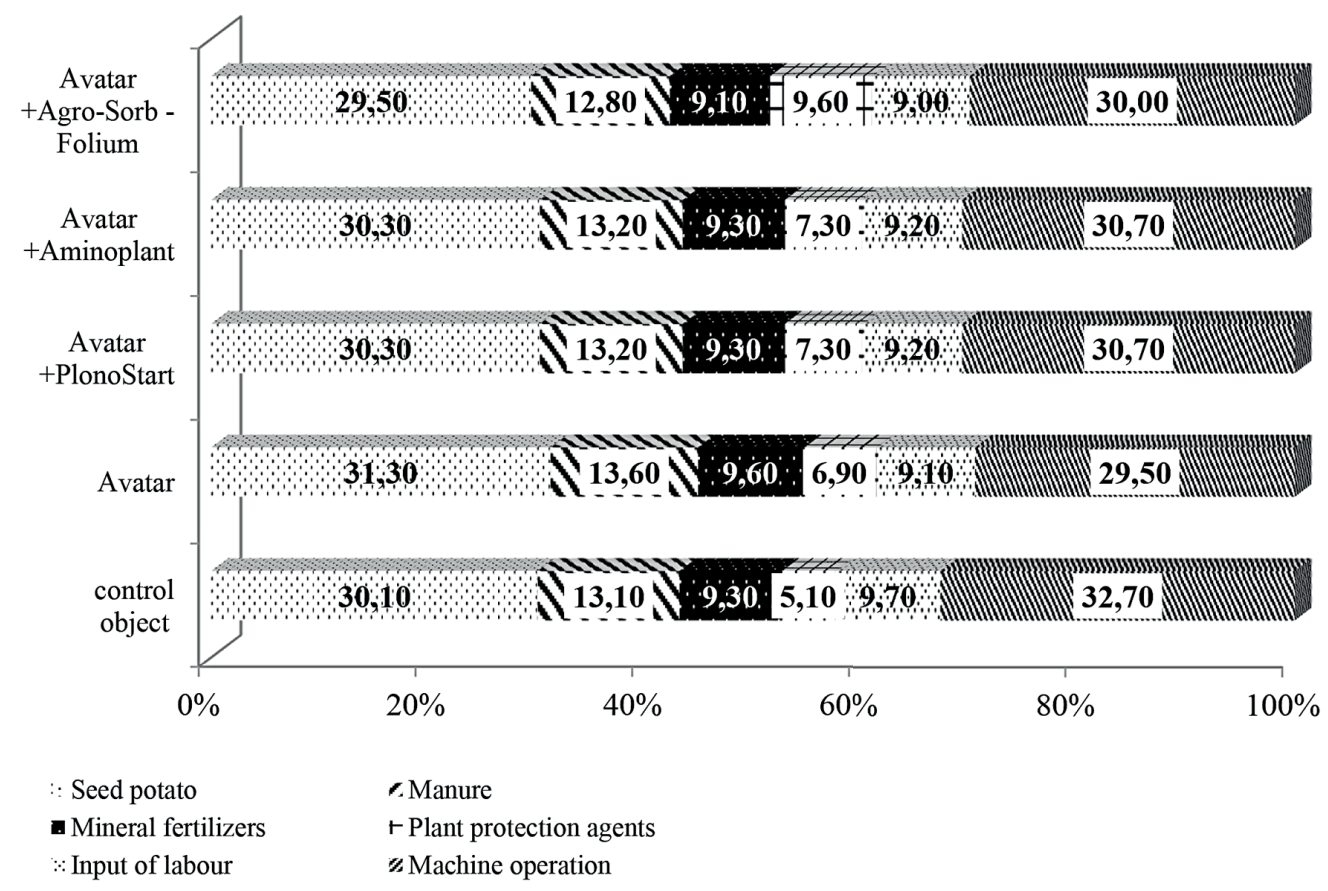

Fig. 1. The direc costs structure in potato cultivation of the Malaga variety 
the value of production were caused by the variation in the size of the yields. The calculations show that the direct surplus per 1 ha of the edible potato cultivar Malaga was the highest in plots 3. and 5. It was from 9554.7 PLN/ha to 11377.9 PLN/ha and was approx. 3 times higher than in the control plot.

\section{CONCLUSIONS}

The conducted research has shown that the most important factor of profitability, at a given price level, is the size of the commercial yield of tubers. The highest yields were obtained from objects mechanically and chemically weeded, where weeds were destroyed using a herbicide with a biostimulator (object 3 and 5). The gross margin indicates that the cultivation of edible potatoes of the Malaga variety in 2018-2020 was profitable.

\section{REFERENCES}

1. Bulgari R., Franzoni G., Ferrante A. 2019. Biostimulants application in horticultural crops under abiotic stress conditions. Agronomy, 9, 306.

2. Drobek M., Fra c M., Cybulska J. 2019. Plant biostimulants: Importance of the quality and yield of horticultural crops and the improvement of plant tolerance to abiotic stress - A review. Agronomy, 9, 335.

3. Dzwonkowski W. 2019. Potato market. Status and prospects. Analizy rynkowe, 46, 1-34.

4. Dzwonkowski W. 2020. Potato market. Status and prospects. Analizy rynkowe, 47, 1-34.

5. Golinowska M. 2009. Chemical plant protection outlays in vast areas farming at the beginning of 21 st century. Journal of Agribusiness and Rural Development, 2(12), 53-60. (in Polish)

6. Gołaś Z. 2016. Economics, organization and income situation of farms in the European Union countries focused on the production of root crops. Roczniki Naukowe Ekonomii Rolnictwa i Rozwoju Obszarów Wiejskich, 103(1), 35-45. (in Polish)

7. Kahlel A.M.S., Sultan F.I. 2019. Response of four potato cultivars to soil application with organic and amino acid compounds. Research On Crops, 20(1), 101-108.
8. Malyshev R., Vinogradova D. 2008. Application of biostimulators from Fe-and Se-nanopowders for competitiveness improvement of agrifood products. Roczniki Naukowe Stowarzyszenia Ekonomistów Rolnictwa i Agrobiznesu, 10(5), 118-121.

9. Muzalewski A. 2015. Principles of selection of agricultural machinery under the RDP for 2014-2020. Wyd. ITP. o/Warszawa: 5-122.

10. Nowacki W. 2016. Table potatoes market in Poland - current state and perspectives. Roczniki Naukowe Stowarzyszenia Ekonomistów Rolnictwa i Agrobiznesu, 18(1), 196-201. (in Polish)

11. Pavlista A.D. 2011. Growth regulators increased yield of Atlantic potato. American Journal of Potato Research, 88, 479-484.

12. Qasim M., Khalid S., Naz A., Khan M.Z. 2013. Effects of different planting systems on field of potato crop in Kaguan Valley: A mountainous region of Pakistan. Agric. Sci., 4(4), 175-179.

13. Roztropowicz S., Czerko Z., Głuska M., Goliszewski W., Gruczek T., Lis B., Lutomirska B., Nowacki W., Wierzejska-Bujakowska A., Zarzyńska K., Zgórska K. 1999. Methodology of observation, measurement and sampling in agricultural experiments with potatoes. Praca zbiorowa. Instytut Hodowli i Aklimatyzacji Roślin. Radzików, Oddział Jadwisin: 1-50.

14. Skarżyńska A., red. 2008. Production, costs and direct surplus of selected agricultural products in 2007. Warszawa: IERiGŻ-PIB, 9-20.

15. Skażyńska A. 2010. Season of selling potatoes for human consumption in the contex of profitability of their production. Journal of Agribusiness and Rural Development, 2(16), 111-123.

16. Trawczyński C. 2021. Assessment of mineral nitrogen fertilization of early potato varieties in integrated production. Journal of Elementology, 26(1), 109123. https://doi.org/10.5601/jelem.2020.25.4.2066

17. Urbanowicz J. 2015. Herbicides recommended for potato protection. Ziemniak Polski, 2, 25-29. (in Polish)

18. Van Oosten M.J., Pepe O., De Pascale S., Silletti S., Maggio A. 2017. The role of biostimulants and bioe_ectors as alleviators of abiotic stress in crop plants. Chem. Biol. Technol. Agric., 4, 5.

19. Wereszczaka J., Marczakiewicz J. 2014. Sustainable agriculture and a healthy environment. Good practices and the role of beneficial microorganisms in the cultivation of potatoes with the use of innovative, natural technologies. Warszawa, MRiRW, Fundacja Programów Pomocy dla Rolnictwa FAPA, 1-97. 